\title{
Introduction to Tourism Management Professional Teaching Method Reform
}

\author{
Lihua Huang \\ School of Languages and International Cultural Exchange, Hainan Tropical Ocean University, \\ Sanya, Hainan, 572022, China \\ 17780065@163.com
}

Keywords: Tourism management; Teaching methods; Reform

\begin{abstract}
The reform of teaching method is an important content of higher education reform, because of the difference of subject characteristics determine the object of teaching. Should possess the quality of the differences in features, objects, and the use of characteristics of single teaching methods, to some extent has deviated from the original intention of professional training objectives. About the applied science, tourism management should adopt new teaching methods such as open teaching in the teaching, to obtain the best teaching effect. This article from the disadvantages of traditional teaching methods and two aspects of tourism management professional teaching reform, three measures for research.
\end{abstract}

\section{Introduction}

Higher education reform is a very important subject in higher education in the 21 st century, it is related to the formation of the talent quality structure, ability structure orientation, market awareness of talent, talent a lot of practical problems such as the rate of return on the market. In terms of the essence of the reform of higher education, its content includes the following aspects: the training mode reform, reform of teaching contents and reform of teaching methods. There is no doubt that three reform content is very important, but in terms of some discipline, and cultivate the innovative and practical talents, method is more important than knowledge. Because the spread of professional knowledge, professional consciousness, literacy and ability to a great extent through certain targeted teaching methods and means to implement. From the perspective of tourism management, reform of teaching method and means is a kind of trend, its success or not will directly affect the overall quality, and the most the tourism professionals. In long engaged in tourism management, on the basis of teaching practice, we have about the reform of the teaching method has carried on the beneficial exploration and attempt, initially formed a mature is different from the traditional teaching method is a new train of thought and practice.

\section{The Disadvantages of Traditional Teaching Methods}

Tourism management is the secondary discipline of management discipline, in terms of professional characteristics, its application is remarkable, operational, and closely linked to the market, belongs to applied science. But from the perspective of the set up of the major education, since most based on a basic subject, therefore are still habitually used traditional teaching methods, teachers' teaching, teaching content and teaching object regardless of class type, all by simply the teacher speak, students listen to a single teaching methods, the students' professional awareness, professional domestic and professional ability.

The main mode of the traditional teaching method for the I"centralizedl", namely the classroom teaching on the basis of teachers teaching and students' listening. From the point of view of the characteristics of the professional, this kind of teaching method is the application of the following disadvantages: 
Only the Interpretation of the Professional Theory Knowledge and Teaching. The lack of practical and operational content, theory, practice, students' practical ability is poor, the so-called applied science becomes hollow. Tourism management involved in the most practical content, need through the students hands-on operation, in practice, is not enough to just by listening.

The \"Centralizedl" Type Teaching Method. It is not conducive to the establishment of student management self-confidence and language expression ability. Tourism management requirements for students' psychological quality is higher, have strong sense of competition and enough self-confidence, four years construct passive to accept knowledge of teaching method is not conducive to the improvement of students' mental quality; Especially the lack of interactive teaching form, more conducive to the students' language competence and the cultivation of the consciousness of public relations.

A Single Teaching Environment and Teaching Mode. Unfavorable to the cultivation of students strain capacity and organization and coordination ability. The professional employment to the vast majority of the students is the travel agencies, hotels and other enterprises, in this kind of uncertainty is the guest services of good strain capacity and organization coordinated ability is a necessary basic quality.

The Long-Term Traditional Teaching Mode that the Teacher Itself Exists in the Update Knowledge and Ability Structure Defect of the Great. It is bound to affect the establishment of the professional students' professional consciousness. As soon as possible to establish professional consciousness is the premise of the students to form a correct understanding of professional, the students' conscious of digging their own potential, targeted to improve the ability of training related professional should possess.

Traditional teaching method is not good for nothing, is still in some of the traditional and basic subject and the main applicable teaching method, and even in the situation of present strongly advocate the teaching method reform, the traditional teaching method combined with other teaching methods and new teaching means can still play a positive role, bring out the best in each other, received good teaching effect. Therefore the use of teaching methods, the key is to play l"suit the remedy to the casel", different characteristics of the subjects should adopt different teaching methods and teaching means.

\section{The Tourism Management Professional Teaching Reform, the Three Measures}

Adjustment of Teaching Contents. According to the tourism management professional training, entrepreneurial, the requirements of the applicable from the quality of talents training target, a series of reform of the teaching content and innovation. On teaching content, for example, to change the original concept of heavy theory, light practice. Teaching content should not only covers the tourism management major should master the basic knowledge, basic theory and basic skills, and to stand in the forefront of science in grasping the tendency of subject development, from a strategic height building facing the $21 \mathrm{st}$ century tourism marketing theory and practice of discipline system. Focus on the cultivation of the students' practical consciousness, pioneering consciousness and ability, such as changing the original theoretical knowledge accounts for a large proportion of pattern, now is the ratio of 7:3 of lay particular stress on theory, the proportion of lay particular stress on practice class is 6:4, pay equal attention to theory and practice of class is the ratio of 5:5. In order to increase the business students in the process of teaching ability and ability of actual combat training, teachers guide students to read the entrepreneur biography, written corporate mission book of tourism, tourist marketing plan, tourism advertising planning, promotion planning book, etc.

The Teaching Method Reform. According to tourism tube professional export-oriented, entrepreneurial, cultivate high-quality personnel training mode and curriculum system and content requirements, in succession on the basis of traditional teaching method, the main reform and innovation of teaching methods should be performed as follows. 
The teaching method of the project: project teaching method is the teachers and students through the implementation of a complete project work together in the teaching activities, is a kind of teaching method in today's international education sector is very popular, especially in the tourist market marketing is more widespread and more used in education. Tourism management teaching emphasizes ।"innovationl" and I"practicel", and more visual basic quality cultivation of tourism marketing, tourism management of marketing mode of thinking methods of training, the development of tourist destination marketing skills and training and the ability to get new knowledge about this exercise.

Sand table simulation teaching method: sand table simulation is tourism management! Introduced a new kind of teaching method, its purpose is to provide students with an opportunity to integrate theory with practice, and education mode of interactive teaching, improve students' interest in learning. Enhance their practical ability, and innovative thinking ability, in order to better integrate the professional knowledge to the practical work. So as to cultivate more practical management talents to satisfy the needs of the society.

Case teaching, case teaching reform at the core of the problem is to break the current pattern of traditional classroom teaching of tourism marketing, reduce the proportion of teachers in classroom teaching, improve students' active participation in classroom teaching, to change

Leather role between teachers and students, in the common thinking and discussion to complete the student ability raise the quantity of product ray process, so as to improve students' ability to analyze problems, solve the problem. Case teaching is to help the students to translate knowledge into skills.

\section{The Reform of the Teaching Means}

The network teaching, the traditional classroom teaching whether is given priority to with the teachers ।"teachingl", is mostly about students ।"learningl" teaching model has obvious flaws, no breakthrough ।"political\", ।"collegel", \"monomial\" operation organization form, is not conducive to the sharing of education resources. In the field of education, because the network education has the basic characteristics of breakthrough time and space limitation and realize resources sharing, the resulting Shared drift, implementation to the learners as the main body of education information and the benefits of learning and collaborative learning, thus network teaching has become an important trend to the world of education reform. But because the network teaching in terms of its essence, and also is a kind of based on certain teaching goal, teachers impart knowledge to students through the network, and promote the development of teaching activities. Compared with traditional teaching, it is a kind of open teaching, provides learners with favorable cognitive learning environment, realize the education resource sharing. In view of the traditional classroom teaching method and I"purel" network auxiliary teaching of focal silver. Put forward the \"classroom teaching, and secondly network teachingl" method of teaching, improve the efficiency of unit teaching time, improve the teaching effect, improve the quality of teaching.

Video teaching video teaching is to develop the television teaching material used in classroom teaching, to enhance the classroom teaching of feeling, have the effect to improve teaching efficiency and quality. Make up for the inadequacy of traditional means, more can highlight important and solve difficult.

Ai the TV video teaching combined with the traditional teaching, to recreation, not only to provide more better and more real perceptual materials, also can attract the attention of the students, stimulate students' interest in learning. To make the students through various senses receive the teaching content, and vivid impression. It is form of teaching, the effective method to improve teaching efficiency and effect.

Practice teaching, in order for students to strengthen the practice ability, we should increase the content of practice teaching, increasing the proportion of practice teaching, carry out various forms of 
practice teaching, in order to enhance the students' practical ability. Such as the department each semester, the qi we are ceos activities, tour guide contest and other activities, exercise the students' practical ability.

\section{Summary}

For tourism management and education, the reform of teaching method is a long-term, the dynamic process of development, to constantly explore, practice and improvement, every teacher has responsibility and obligation to pay attention to the teaching reform, as a practitioner of teaching reform, and enabler.

\section{Acknowledgement}

This research was financially supported by the Education and Teaching Reform Project of Hainan Tropical Ocean University(No.RDJGb2016-56).

\section{References}

[1] Q.R. Wang: On the Training Mode of Experiential Teaching Talents in Tourism Management Specialty, Tourism Tribune, (2006) No.S1, p.89-92.

[2] J.F. Mao, Y.J. Zhang: On the Reform of Undergraduate Teaching Mode of Tourism Management Specialty, Journal of Shenyang Normal University (Social Science Edition), Vol. 30 (2006) No.5, p.9-11.

[3] H.X. Zou: Research on the Reform of Training Objectives and Curriculum System of Higher Tourism Management, Journal of Yunmeng, (2004) No.1, p.99-101.

[4] X.Y. Jiang, J. Wu, Y.L. Huang: A Survey on the Current Situation of Tourism Management Course System and Its Innovation - A Case Study of Tourism Management Specialty in Guilin University of Technology, Journal of Guilin Institute of Tourism, (2003) No.4, p.70-76.

[5] Y.F. Chen: Pursuit of International Trend and Reform the Curriculum System of Colleges and Universities, China Higher Education, (2002) No.Z1, p.2.

[6] Q. Wei, J.J. Zeng: Research on the Innovation of Teaching Mode of Tourism Management Specialty, Journal of Jiangxi Radio \& TV University, (2008) No.4, p.91-93.

[7] C.C. Jiang: Current Situation and Reform Thinking of Undergraduate Education in Tourism Management, Journal of Putian University, Vol. 11 (2004) No.4, p. 39-41+79. 